\title{
MODEL PEMBERDAYAAN HUKUM PEMBUDI DAYA IKAN MELALUI PENDEKATAN PENGEMBANGAN MODEL TRIPLE HELIX (STUDI DI KABUPATEN GRESIK)
}

\section{MODEL OF EMPOWERMENT LAW FISH FARMER THROUGH TRIPLE HELIX MODEL APPROACH (CASE STUDY IN GRESIK REGENCY)}

\author{
Eny Sulistyowati \\ Fakultas Ilmu Sosial dan Hukum Universitas Negeri Surabaya \\ Muh. Ali Masnun \\ Fakultas Ilmu Sosial dan Hukum Universitas Negeri Surabaya \\ alimasnun@unesa.ac.id \\ Mahendra Wardhana \\ Fakultas Ilmu Sosial dan Hukum Universitas Negeri Surabaya \\ Arinto Nugroho \\ Fakultas Ilmu Sosial dan Hukum Universitas Negeri Surabaya \\ Nurul Hikmah \\ Fakultas Ilmu Sosial dan Hukum Universitas Negeri Surabaya
}

\begin{abstract}
Abstrak
Pembudi daya ikan memiliki kontribusi nyata dalam pembanguan ekonomi nasional melalui jumlah produksi perikanan. Kontribusi tersebut tidak diikuti tingkat kesejahteraan bagi para pembudi daya dengan pendapatan yang diperoleh relatif masih sangat terbatas. Artikel ini bertujuan menganalisis model pemberdayaan hukum pembudi daya ikan melalui pendekatan pengembangan model triple helix. Penelitian merupakan sociolegal research yang merupakan metode hasil perkawinan antara metode penelitian hukum dengan ilmu sosial. Hasil penelitian menunjukkan bahwa secara normatif, ketentuan peran dari pemerintah dan pembudi daya ikan telah diatur secara jelas, namun ketentuan bagi akademia sebagai salah satu stakeholder yakni perguruan tinggi belum diatur, padahal peran yang diemban perguruan tinggi juga tidak kalah penting. Perguruan tinggi sebagai salah satu unsur dalam triple helix memiliki sumber daya manusia yang mampu memberikan pengetahuan dan pemahaman terkait dengan perjanjian bagi hasil melalui legal assistance maupun workshop pendampingan. Pemerintah bertanggung jawab atas kesejahteraan warga negaranya, tidak hanya berperan sebagai regulator, tetapi juga fasilitator, dinamisator, dan katalisator.
\end{abstract}

Kata kunci : Pemberdayaan Hukum, Pembudi Daya Ikan, Triple Helix 


\begin{abstract}
The real contribution of fish farmer in the development of the national economy through the amount of fisheries production is not followed by the level of welfare of the fish farmer. That the welfare of fish farmers to be able to fulfill their needs with the income they obtain is still very limited. This article aims to analyze the legal empowerment model of fish farmer through the triple helix model development approach. This research is a sociolegal research which is a mixed method between legal research methods and social science. The data used are primary data and secondary data. The results showed that normatively, the role provisions of the government and fish breeders have been clearly regulated, but the provisions for tertiary institutions have not been regulated, even though the role played by universities is no less important. Higher education as one of the elements in the triple helix has human resources who are able to provide knowledge and understanding related to production sharing agreements through legal assistance and mentoring workshops. The government is responsible for the welfare of its citizens, not only acting as a regulator, but also as a facilitator, dynamist and catalyst.
\end{abstract}

Keywords : Legal Empowerment, Fish Farmer,Triple Helix

\section{A. Pendahuluan}

Amanah Pancasila dan UndangUndang Dasar Negara Republik Indonesia Tahun 1945 (untuk selanjutnya disingkat UUD NRI 1945) bahwa salah satu filosofi dasar pembangunan bangsa ialah mewujudkan keadilan sosial bagi seluruh rakyat Indonesia. Pembangunan di bidang ekonomi, Pasal 33 ayat (3) UUD NRI 1945 menegaskan bahwa "Bumi dan air dan kekayaan alam yang terkandung di dalamnya dikuasai oleh negara dan dipergunakan untuk sebesar-besar kemakmuran rakyat" ketentauna sebagaimana tersebut dapat ditafirkan bahwa Indonesia merupakan bentuk model negara kesejahteraan Indonesia yang memadukan peran ekstensif negara dalam usaha kesejahteraan sosial (universal welfare state) dengan social insurance welfare state ${ }^{l}$.

Pembangunan ekonomi yang patut menjadi perhatian adalah bidang kekayaan laut. Kekayaan laut sektor perikanan sebagai salah satu potensi kekayaan laut perlu dikelola secara optimal, sebagaimana diungkapkan Endang Retnowati bahwa sumber daya ikan adalah salah satu sumber ekonomi yang dapat dijadikan sebagai modal bagi pembangunan bangsa Indonesia ${ }^{2}$. Berdasarkan Laporan Kinerja

\footnotetext{
1 Yudi Latif, Negara Paripurna: Historisitas, Rasionalitas, Dan Aktualitas Pancasila (Jakarta: PT Gramedia, 2011).

2 Endang Retnowati, 'Nelayan Indonesia Dalam Pusaran Kemiskinan Struktural (Perspektif Sosial, Ekonomi Dan Hukum)', Perspektif, XVI.3 (2011).
} 
Kementerian Kelautan dan Perikanan Tahun 2016, bahwa Tahun 2016 produksi perikanan yang dihasilkan oleh seluruh kabupaten/kota meliputi perikanan tawar, payau, dan laut (termasuk rumput laut) sebesar 23,51 juta ton dari target 23,43 juta ton atau mencapai $100,33 \%$. Komposisi produksi perikanan di tahun 2016 disumbangkan dari produksi perikanan tangkap sebesar 6,83 juta ton atau 29,06\%, dibandingkan dengan sumbangan dari produksi perikanan budidaya sebesar 16,67 juta ton atau $70,94 \%{ }^{3}$.

Sumbangan produksi perikanan budi daya air ikan yang relatif cukup besar, merupakan kontribusi yang dihasilkan oleh daerah-daerah penghasil perikanan budi daya. Salah satunya adalah kontribusi dari Kabupaten Gresik yang menempati peringkat pertama di Provinsi Jawa Timur berdasarkan jumlah pembudidaya ikan, luas areal budidaya ikan, jumlah produksi ikan dan nilai produksi ikan.

Kontribusi nyata tersebut, berbanding terbalik dengan tingkat kesejahteraan bagi para pembudi daya ikan yaitu orang yang mata pencahariannya melakukan pembudidayaan ikan air tawar, ikan air payau maupun ikan air laut. Permen KP Renstra 2015-2019 memaparkan bahwa

\footnotetext{
${ }^{3}$ Kementerian Kelautan dan Perikanan Republik Indonesia, Laporan Kinerja Kementerian Kelautan Dan Perikanan Tahun 2016 (Jakarta, 2016).
}

kesejahteran para pembudidaya ikan untuk dapat memenuhi kebutuhan dengan pendapatan yang diperolehnya masih sangat terbatas. Kesejahteraan adalah pilar penting yang menjadi tujuan sekaligus tolok ukur dari berhasil tidaknya pembangunan perikanan. Pembangunan perikanan harus menjawab permasalahan krusial yang dihadapi sektor ini, yaitu kemiskinan, karena faktanya nelayan hingga saat ini termasuk dalam kelompok masyarakat termiskin dari kelompok masyarakat lainnya. Salah satu penyebab hal tersebut adalah sistem bagi hasil yang tidak adil dan tekanan dari pemilik modal. Kondisi kemiskinan yang dialami nelayan menyebabkan mereka rentan konflik dan hanya menjadi objek ${ }^{4}$. Hal senada diungkapkan Muhajir bahwa sistem bagi hasil yang terjadi selama ini, proposi bagian nelayan penggarap selalu tetap dan cenderung sangat kecil dibandingkan dengan pendapatan pemilih lahan ditambah dengan kenyataan bahwa nelayan penggarap dan pemilik lahan memiliki posisi tawar yang lemah baik secara ekonomi maupun politik karna dihadapkan dengan struktur pasar yang tidak kondusif ${ }^{5}$.

\footnotetext{
${ }^{4}$ Retnowati.

${ }^{5}$ Moh. Nafri Muhajir, Osgar S. Matompo, 'Legal Analysis Of Land Fisheries Result Agreement According To Law No. 16 Of Year 1964 About
} 
Berkaitan dengan hal tersebut, maka negara harus hadir dan bertanggung jawab dalam memberikan perlindungan dan pemberdayaan bagi pembudi daya ikan yaitu berupa upaya untuk membantu pembudi daya ikan dalam menghadapi permasalahan kesulitan yang mereka alami. Peran negara tidak bisa dipisahkan dengan konsep Welfare State karena negara hadir dianggap sebagai jawaban yang paling tepat atas bentuk keterlibatan negara dalam memajukan kesejahteraan rakyat ${ }^{6}$ yang dalam konteks ini negara yang berperan dalam mengelola perekonomian, yang yang di dalamnya mencakup tanggung jawab negara untuk memberikan perlindungan dan pemberdayaan kepada pembudi daya ikan, mengingat negara Indonesia adalah negara maritim dengan sebagian besar luas wilayahnya berupa lautan, jangan sampai peribahasa "anak ayam mati di lumbung padi" benar-benar ada dan terjadi. Perlindungan dan pemberdayaan merupakan bentuk pembangunan kesejahteraan sosial di Indonesia yang

The Fishery Outcomes Pattern', Jurnal Kolaboratif Sains, 1.1 (2019), 1543.

${ }^{6}$ Dan Absori Elviandri, Khuzdaifah Dimyati, 'Quo Vadis Negara Kesejahteraan: Meneguhkan Ideologi Welfare State Negara Hukum Kesejahteraan Indonesia', Mimbar Hukum - Fakultas Hukum Universitas Gadjah Mada, 31.2 (2019), 253. mengacu pada konsep negara kesejahteraan.

Sebagaimana termaktub dalam Penjelasan Umum Undang-Undang Nomor 7 Tahun 2016 tentang Perlindungan dan Pemberdayaan Nelayan, Pembudi Daya Ikan, dan Petambak Garam (untuk selanjutnya disebut UU Pemberdayaan) bahwa dalam pengembangan perikanan budidaya, permasalahan kesejahteraan tersebut salah satunya terkait kurangnya jaminan kepastian hukum serta keadilan bagi pembudi daya ikan. Menyikapi hal tersebut, telah diatur dalam Pasal 28 UU Pemberdayaan ayat (1), (3), dan (4) yang menyebutkan bahwa:

(1) Pemilik dan penyewa kapal atau Pemilik Lahan Budi Daya dan penyewa lahan budi daya yang melakukan kegiatan Penangkapan Ikan atau Pembudidayaan Ikan dengan melibatkan Nelayan Kecil, Nelayan Tradisional, Nelayan Buruh, atau Penggarap Lahan Budi Daya harus membuat perjanjian kerja atau perjanjian bagi hasil secara tertulis.

(3) Pemerintah Daerah berkewajiban memberikan pendampingan kepada Nelayan Kecil, Nelayan Tradisional, Nelayan Buruh, Penggarap Lahan Budi Daya, dan Penggarap Tambak Garam dalam membuat perjanjian kerja atau perjanjian bagi hasil sebagaimana dimaksud pada ayat (1) dan ayat (2).

(4) Perjanjian sebagaimana dimaksud pada ayat (1) dan ayat (2) dilakukan berdasarkan prinsip adil, menguntungkan bagi kedua belah pihak, dan mempertimbangkan kearifan lokal. 
Ketentuan lain dalam UU Pemberdayaan pada Pasal 12 ayat (3) menyatakan bahwa strategi pemberdayaan dilakukan melalui pendidikan dan pelatihan, penyuluhan dan pendampingan, kemitraan usaha, kemudahan akses ilmu pengetahuan, teknologi, dan informasi, dan penguatan kelembagaan. Adapun stakeholder yang terlibat dalam pemberdayaan tersebut sebagaimana diatur dalam UU Pemberdayaan meliputi pembudidaya ikan, pemerintah (pusat dan daerah), dan pelaku usaha.

Berkaitan dengan tersebut, berdasarkan hasil penelitian yang telah peneliti lakukan menunjukkan jika perjanjian bagi hasil yang dilakukan pembudi daya ikan di Kabupaten Gresik masih belum diterapkan sama sekali sebagaimana ketentuan Pasal 28 UU Pemberdayaan.

Penelitian sejenis pernah dilakukan oleh Ria Ayu Novita dengan fokus kajian pada aspek efektivitas pelaksanaan Undang-undang Nomor 2 Tahun 1960 mengenai perjanjian bagi hasil tanah pertanian di Kabupaten Purworejo 7. Penelitian lain yang sejenis juga dilakukan

\footnotetext{
${ }^{7}$ Suparno Ria Ayu Novita, Agung Basuki Prasetyo, 'Efektivitas Pelaksanaan Undang-Undang Nomor 2 Tahun 1960 Mengenai Perjanjian Bagi Hasil Tanah Pertanian Di Kabupaten Purworejo', Diponegoro Law Journal, 6.2 (2017), 1.
}

oleh Muhajir yang isu yang diteliti mengenai perjanjian bagi hasil perikanan darat di desa Bolano Kecamatan Bolano Kabupaten Parigi Moutong Menurut Undang Nomor 16 Tahun 1964 Tentang Pola Bagi Hasil Perikanan ${ }^{8}$. Maria Christina dalam tesisnya melaksanakan penelitian dengan kajian Pelaksanaan Bagi Hasil Perikanan Laut menurut hukum adat setelah keluarnya UU Nomor 16 tahun 1964 di Kelurahan Tanjung Mas Kecamatan Semarang Utara Kota Semarang 9 .

Tujuan dari penelitian ini untuk menganalisis bagaimana model pemberdayaan dengan model dasar triple helix dengan mengembangkan pada pemberdayaan hukum hubungan jejaring antar stakeholder melalui pendekatan pengembangan model triple helix, mengingat jejaring sangat berperan dalam menentukan keberhasilan pemberdayaan hukum bagi pembudidaya ikan di sebuah wilayah.

\section{B. Metode Penelitian}

\footnotetext{
${ }^{8}$ Muhajir, Osgar S. Matompo.

9 Maria Christina PV, 'Pelaksanaan Bagi Hasil Perikanan Laut Menurut Hukum Adat Setelah Keluarnya UU Nomor 16 Tahun 1964 (Suatu Studi Terhadap Kesejahteraan Nelayan Penggarap Di Perkampungan Nelayan Tambak Lorok Kelurahan Tanjung Mas Kecamatan Semarang Utara Kota Semarang.' (Universitas Diponegoro, 2004).
} 
Tipe penelitian yang digunakan dalam penelitian ini dapat dikategorikan sebagai penelitian sociolegal yang merupakan metode hasil perkawinan antara metode penelitian hukum dengan ilmu sosial ${ }^{10}$. Artinya tidak hanya melihat hukum itu sendiri (tidak terkungkung menjadi penelitian dogmatis), melainkan juga mengaitkan dengan ilmu sosial lain. Aspek normativitas hukum dengan menelusuri bahan hukum yang relevan khususnya UU Pemberdayaan untuk kemudian mencermati bagaimana formulasi norma dalam peraturan perundang-undangan terkait dengan pemberdayaan hukum pembudi daya ikan. Aspek nonhukum meliputi konsep triple helix sebagai basis pengembangan yang didasarkan data yang diperoleh melalui wawancara dengan informan.

\section{Pembahasan}

Pemberdayaan menurut Wrihatnolo merupakan suatu kegiatan yang berkesinambungan, dinamis, secara sinergis mendorong keterlibatan semua potensi yang ada secara evolutif dengan

\footnotetext{
${ }^{10}$ Sulistyowati Irianto, Metode Penelitian Hukum: Konstelasi Dan Refleksi (Yogyakarta: Yayasan Pustaka Obor Indonesia, 2011).
} $\begin{array}{lcc}\text { keterlibatan } & \text { semua } & \text { potensi } \\ \text { Pemberdayaan } & & \text { memungkinkan }\end{array}$ terbentuknya masyarakat majemuk yang penuh keseimbangan hak dan kewajiban, saling menghormati tanpa ada yang merasa asing dalam komunitasnya. Tujuan dari pemberdayaan adalah untuk membentuk individu dan masyarakat menjadi mandiri. Kemandirian tersebut meliputi kemandirian berfikir, bertindak dan mengendalikan apa yang mereka lakukan tersebut. Kemandirian masyarakat adalah merupakan suatu kondisi yang dialami oleh masyarakat yang ditandai oleh kemampuan untuk memikirkan, memutuskan serta melakukan sesuatu yang dipandang tepat demi mencapai pemecahan masalah-masalah yang dihadapi dengan mempergunakan daya kemampuan yang terdiri atas kemampuan kognitif, konatif, psikomotorik, afektif, dengan mengerahkan sumber daya yang dimiliki oleh lingkungan internal masyarakat tersebut.

Pasal 1 angkat 2 UU Pemberdayaan menyebutkan pemberdayaan adalah segala upaya untuk meningkatkan kemampuan pembudi daya ikan untuk melaksanakan usaha perikanan secara lebih baik, dalam konteks ini pemberdayaan yang dilakukan

\footnotetext{
11 Wrihatnolo dan Dwidjowijoto, Manajemen Pemberdayaan (Jakarta: Elex Media Komputindo, 2007).
} 
lebih pada bagaimana manajemen budi daya ikan. Berkaitan dengan pemberdayaan hukum tersebut mengandung makna bagaimana upaya untuk meningkatkan kemampuan, pengetahuan, dan pemahaman pada aspek hukum (dalam konteks ini adalah perjanjian bagi hasil).

Pemberdayaan hukum bagi masyarakat dengan kondisi ekonomi yang tidak mampu diharapkan dapat memberi kesempatan bagi mereka untuk dapat ikut berpartisipasi memperjuangkan haknya untuk memperoleh kehidupan yang lebih baik dalam hal ini adalah terkait dengan perjanjian kerjasama dan perjanjian bagi hasil. Dari definisi tersebut dapat dimaknai bahwa pemberdayaan merupakan segala upaya untuk meningkatkan kemampuan.

Berkaitan dengan pemberdayaan hukum mengandung makna bagaimana upaya untuk meningkatkan kemampuan, pengetahuan, dan pemahaman pada aspek hukum (dalam konteks ini adalah perjanjian bagi hasil). Pemberdayaan hukum dibutuhkan oleh masyarakat miskin/masyarakat yang dimarjinalkan oleh hukum.

Mengacu pada Pasal 3 UU Pemberdayaan Pembudi Daya Ikan bertujuan untuk: a. menyediakan prasarana dan sarana yang dibutuhkan dalam mengembangkan usaha;

b. memberikan kepastian usaha yang berkelanjutan;

c. meningkatkan kemampuan dan kapasitas Nelayan, Pembudi Daya Ikan, dan Petambak Garam; menguatkan kelembagaan dalam mengelola sumber daya ikan dan sumber daya kelautan serta dalam menjalankan usaha yang mandiri, produktif, maju,modern, dan berkelanjutan; dan mengembangkan prinsip kelestarian lingkungan;

d. menumbuhkembangkan sistem dan kelembagaan pembiayaan yang melayani kepentingan usaha;

e. melindungi dari risiko bencana alam, perubahan iklim, serta pencemaran;dan

f. memberikan jaminan keamanan dan keselamatan serta bantuan hukum.

Tujuan pemberdayaan akan begitu berarti jika tidak hanya pada aspek normatif saja, melainkan juga pada tataran implementasi. Aspek penyediaan sarana prasarana, kepastian usaha, peningkatan kemampuan, perlindungan atas risiko, dan jaminan keamanan adalah tujuan dari kehadiran hukum dalam pemberdayaan hukum. Fakta di lapangan tampak bahwa penerapan perjanjian bagi hasil di 
Kabupaten Gresik masih belum dapat diimplementasikan. Kondisi hukum yang demikian ini mengakibatkan kesenjangan antara apa yang terjadi di masyarakat dan apa yang ada dalam norma hukum. Apa yang diajarkan oleh doktrin dan apa yang diperintahkan oleh norma hukum menjadi sulit direalisasikan. Kesulitan tersebut terbentur dengan apa yang telah tertradisikan di dalam masyarakat atau yang telah diparadigmakan dalam ajaran hukum murni dari kaum legis.

Upaya pemberdayaan hukum melibatkan beberapa pihak/stakeholder yang antara pihak/stakeholder harus bersinergi secara baik hingga pada akhirnya para pihak (terutama pembudi daya ikan) benar-benar dapat diberdayakan dari aspek hukum dan mampu memberikan manfaat bagi semua pihak. Model sinergi antara para pihak salah satunya ada konsep triple helix dikenalkan oleh Etzkowitz \& Leydesdorff. Pada dasarnya konsep triple helix merupakan interaksi antara universitas, industri dan pemerintah. Konsep ini sering digunakan sebagai kerangka normatif untuk pemahaman interaksi antara para pihak dalam inovasi sebuah sistem. Selain itu juga menjadi strategi umum yang digunakan pemerintah dalam mengembangkan inovasi suatu kebijakan. Dalam konteks penelitian ini maka, bagaimana konsep model triple helix dapat dikembangkan dalam pemberdayaan pembudidaya ikan. Salah satu klaim utama dari tesis triple helix adalah bahwa antara akademisi, industri dan pemerintah menyediakan kondisi yang optimal untuk inovasi ${ }^{12}$. Industri dalam konteks penelitian ini dikembangkan menjadi pembudi daya ikan.

Pemerintah bertanggung jawab atas tujuan Negara sebagaimana telah menjadi konsensus founding fathers, sehingga tanggung jawab penuh berkaitan dengan hal tersebut melekat kepada pemerintah. Regulasi dan kebijakan program pembangunan untuk menstimulus pembudi daya ikan memberikan pendampingan pemahaman sekaligus memastikan perjanjian bagi hasil dapat diterapkan. Pemerintah dengan segala tanggung jawab dan kewenangannya perlu berkolaborasi sekaligus sinergi dengan akademia perguruan tinggi untuk transfer of knowledge, utamanya terkait pentingnya perjanjian bagi hasil dalam bentuk tertulis. Pembudi daya ikan yang berperan sebagai objek yang diberdayakan, karena berdasarkan hasil penelitian yang dilakukan tingkat kesejahteraan pembudidaya ikan relatif masih di bawah rata-rata, sementara pemerintah adalah

12 Loet Leydesdorff and Henry Etzkowitz, The Triple Helix as a Model for Innovation Studies, Science and Public Policy 25(3), 195-203., 1998. 
sumber hubungan kontraktual yang memastikan interaksi dan pertukaran yang stabil, dan universitas sebagai sumber pengetahuan baru. Sinergi dari ketiga ini merupakan prinsip generative dalam membangun ekonomi yang lebih erat.

Berdasarkan hasil analisis bahwa secara normatif peran pemerintah begitu sentral dalam pemberdaya jika dibandingkan dengan stakeholder lainnya. Jika ditelaah maka ketentuan dalam UU Pemberdayaan, bahwa peran pemerintah daerah dalam pemberdayaan masyarakat yaitu terbagi menjadi empat peran antara lain:

a) Pemerintah sebagai regulator

Pemerintah sebagai regulator dalam konteks ini, berarti pemerintah menyiapkan arah untuk menyeimbangkan penyelenggaraan pembangunan melalui penerbitan peraturan-peraturan. Sebagai regulator, pemerintah memberikan acuan dasar kepada masyarakat sebagai instrumen untuk mengatur segala kegiatan pelaksanaan pemberdayaan. Regulasi yang sudah dihasilkan pemerintah juga perlu disosialisasikan kepada masyarakat luas, utamanya pembudi daya ikan. UU Pemberdayaan telah memberikan arah pengaturan pemberdayaan melalui pendampingan dan memastikan adanya perjanjian tertulis.

b) Pemerintah sebagai dinamisator

Peran pemerintah sebagai dinamisator adalah menggerakkan partisipasi masyarakat jika terjadi kendalakendala dalam proses pembangunan untuk mendorong dan memelihara dinamika pembangunan daerah. Pemerintah berperan melalui pemberian bimbingan dan pengarahan secara intensif dan efektif kepada masyarakat. Bimbingan dan pengarahan danlam konteks ini diwujudkan melalui tim penyuluh maupun badan tertentu untuk memberikan pelatihan, namun demikian penyuluh dari kabupaten yang ada langsung di bawah dinas belum berjalan secara optimal, khususnya dalam hal memastikan dan pendampingan perjanjian tertulis.

c) Pemerintah sebagai fasilitator

Peran pemerintah sebagai fasilitator mengandung arti menciptakan kondisi yang kondusif bagi pelaksanaan pembangunan (menjembatani kepentingan berbagai pihak dalam mengoptimalkan pembangunan daerah). Sebagai fasilitator, pemerintah berusaha menciptakan atau menfasilitasi suasana yang tertib, nyaman dan aman, termasuk 
menfasilitasi tingkat pengetahuan dan pemahaman para pembudi daya ikan.

d) Pemerintah sebagai katalisator

Pemerintah berposisi sebagai agen yang mempercepat pengembangan potensi daerah dan negara yang kemudian bisa menjadi modal sosial untuk membangun partisipasi.

Stakeholder lain yang merupakan objek atau target dari pemberdayaan adalah pembudi daya ikan, dalam hal ini terdiri dari pemilik lahan budi daya, penggarap lahan budidaya, dan penyewa lahan budidaya. Para pemilik, penggarap, dan penyewa merupakan para pihak yang terlibat dalam perjanjian, sehingga tingkat kesadaran hukum (baik pada aspek pengetahuan, pemahaman, sikap, dan perilaku) benar-benar dapat diimplementasikan. Perjanjian di bawah tangan yang turun temurun dan menjadi sebuah kebiasaan, tanpa memperhatikan tentu akan memiliki konsekuensi yang berpotensi muncul sengketa sebelum, saat, atau pasca panen. Mungkin saat ini, belum ada preseden berkaitan dengan hal yang berpotensi atau adanya kekhawatiran. Tetapi dinamika kehidupan yang tidak bisa kita prediksi, sebagai orang tentu butuh sebuah akan kepastian atas perjanjian/akad yang mengikat antara para pihak satu dengan yang lain.
Perjanjian di bawah tangan tetap tidak memiliki kepastian hukum antara para pihak dan sangat berpotensi atau riskan ada yang dirugikan salah satu pihak. Berandai-andai saja, bagaimana jika kerugian atau tidak untungnya panen itu atas kelalaian yang dilakukan oleh penggarap? Padahal pembudidaya sudah mengeluarkan modal yang tidak sedikit.

Para pemilik, penyewa, dan penggarap budi daya ikan tingkat desa/kelurahan telah memiliki kelompok pembudi daya ikan (POKDAKAN) yang dalam hal ini dapat dikatakan bisa membawa informasi penting terkait isu-isu budi daya ikan, tidak hanya berkaitan dengan teknik budi daya, manajemen budi daya atau yang lain tetapi berkaitan dari aspek hukum paling tidak POKDAKAN mampu berperan aktif guna menunjang untuk meningkatkan tingkat kesadaran akan pentingnya perjanjian tertulis.

Stakeholder lain yang juga tidak kalah penting adalah akademia, dalam konteks penelitian ini adalah universitas/perguruan tinggi, namun demikian secara normatif, regulasi yang melibatkan perguruan tinggi belum diatur dalam UU Pemberdayaan. Perguruan Tinggi dengan Tridharma telah menyebutkan bahwa bahwa kewajiban dosen adalah melakukan pendidikan, penelitian, dan pengabdian kepada 
masyarakat. Dharma ketiga perguruan tinggi telah menyatakan dengan jelas peran akademisi perguruan tinggi terhadap kebutuhan masyarakat umum yang sesuai dengan kapasitas dan kapabilitasnya. Sedangkan pada dharma pertama dan keduanya, akademisi perguruan tinggi dituntut tidak hanya untuk mengajarkan ilmunya pada mahasiswa, namun juga melakukan penelitian yang mengarah pada penemuan-penemuan kreatif yang mendukung perkembangan ilmu pengetahuan secara teoritik maupun praktis.

Jika selama ini pemenuhan share knowledge hanya terjadi di dalam kalangan pendidikan, antara dosen dengan mahasiswa, maka dengan triple helix diharapkan pihak akademisi juga memegang peran penting dan bertanggung jawab dalam permasalahan sosial masyarakat dalam konteks penelitian ini berarti adalah pembudi daya ikan. Perguruan tinggi atau universitas dalam mencetak manusia-manusia dengan gelar akademiknya harus mampu mentransfer keilmuan itu untuk meningkatkan ekonomi bangsa secara umum. Pemerintah selama ini dengan program-programnya sudah banyak melakukan untuk meningkatkan peran universitas dalam memajukan perekonomian bangsa. Akademisi universitas memainkan peran kunci dalam pengembangan pengetahuan dan pemahaman yang akan ditransferkan pada pembudi daya ikan untuk perjanjian bagi hasil. Berdasarkan ilustrasi tersebut maka model pemberdayaan masyarakat yang dapat dilakukan adalah sebagaimana tersaji dalam bagan 1

Bagan 1

Model Pengembangan Triple Helix dalam Pemberdayaan Hukum Pembudi Daya Ikan

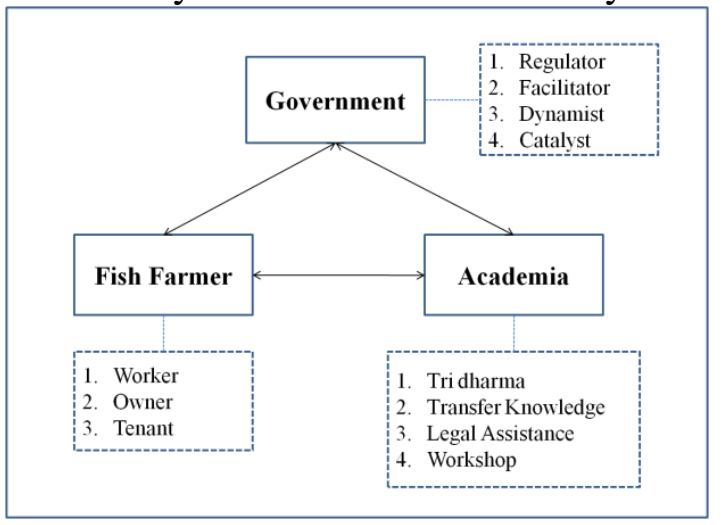

Pemerintah merupakan stakeholder utama yang memiliki peran begitu sentral, pemerintah tidak hanya sebagai regulator, melainkan juga dinamisator, fasilitator, dan juga katalisator. Akademia sebagai salah satu stakeholder sampai saat ini belum ada pengaturannya dalam UU Pemberdayaan. Menjadi penting pelibatan akademia dalam konteks ini adalah perguruan tinggi atau universitas yang akan melakukan transfer pengetahuan sebagai salah satu bentuk dari tiga dharma perguruan tinggi, yakni dharma pengabdian. Stakeholder yang merupakan objek atau target pemberdayaan perlu memiliki tingkat kesadaran hukum 
mengenai pentingnya perjanjian tulis dalam budi daya ikan.

\section{Kesimpulan}

Berdasarkan uraian sebelumnya dapat disimpulkan bahwa sinergi antara stakeholder dalam konsep triple helix baik pemerintah, pembudi daya, dan akademisi merupakan salah satu kunci keberhasilan model pemberdayaan hukum bagi pembudi daya ikan di Kabupaten Gresik. Pemberdayaan sebagai salah satu kunci bagaimana pembudi daya ikan menjadi individu yang memiliki kemandirian berfikir, bertindak dalam hal perjanjian bagi hasil perlu mengoptimalkan sinergi dan kolaborasi antara stakeholder yang terlibat, dalam hal ini pemerintah, pembudi daya ikan, dan juga akademia perguruan tinggi yang saat ini belum diatur secara normatif dan belum diimplementasikan.

\section{Buku}

\section{Daftar Pustaka}

Indonesia, Kementerian Kelautan dan Perikanan Republik, Laporan Kinerja Kementerian Kelautan Dan Perikanan Tahun 2016 (Jakarta, 2016)

Irianto, Sulistyowati, Metode Penelitian Hukum: Konstelasi Dan Refleksi (Yogyakarta: Yayasan Pustaka Obor Indonesia, 2011)

Latif, Yudi, Negara Paripurna: Historisitas, Rasionalitas, Dan
Aktualitas Pancasila (Jakarta: PT Gramedia, 2011)

Wrihatnolo dan Dwidjowijoto, Manajemen Pemberdayaan (Jakarta: Elex Media Komputindo, 2007)

\section{Karya Ilmiah}

Elviandri, Khuzdaifah Dimyati, Dan Absori, 'Quo Vadis Negara Kesejahteraan: Meneguhkan Ideologi Welfare State Negara Hukum Kesejahteraan Indonesia', Mimbar Hukum - Fakultas Hukum Universitas Gadjah Mada, 31.2 (2019), 253

Etzkowitz, Loet Leydesdorff and Henry, The Triple Helix as a Model for Innovation Studies, Science and Public Policy 25(3), 195-203., 1998

Muhajir, Osgar S. Matompo, Moh. Nafri, 'Legal Analysis Of Land Fisheries Result Agreement According To Law No. 16 Of Year 1964 About The Fishery Outcomes Pattern', Jurnal Kolaboratif Sains, 1.1 (2019), 1543

PV, Maria Christina, 'Pelaksanaan Bagi Hasil Perikanan Laut Menurut Hukum Adat Setelah Keluarnya UU Nomor 16 Tahun 1964 (Suatu Studi Terhadap Kesejahteraan Nelayan Penggarap Di Perkampungan Nelayan Tambak Lorok Kelurahan Tanjung Mas Kecamatan Semarang Utara Kota Semarang.' (Universitas Diponegoro, 2004)

Retnowati, Endang, 'Nelayan Indonesia Dalam Pusaran Kemiskinan Struktural (Perspektif Sosial, Ekonomi Dan Hukum)', Perspektif, XVI.3 (2011)

Ria Ayu Novita, Agung Basuki Prasetyo, Suparno, 'Efektivitas Pelaksanaan Undang-Undang Nomor 2 Tahun 
1960 Mengenai Perjanjian Bagi Hasil Tanah Pertanian Di Kabupaten Purworejo', Diponegoro Law Journal, 6.2 (2017), 1

\section{Peraturan Perundang - Undangan}

Undang-Undang Republik Indonesia Nomor 7 Tahun 2016 Perlindungan dan Pemberdayaan Nelayan, Pembudi Daya Ikan, dan Petambak Gara. Lembaran Negara Republik Indonesia Tahun 2016 Nomor 68. Jakarta.

Undang-Undang Nomor 2 Tahun 1960 Tentang Perjanjian Bagi Hasil Tanah Pertanian 